\begin{tabular}{|c|c|}
\hline journal of sociologicalcontext & $\begin{array}{r}\text { ISSN: } 2757-5942 \\
2020,1(1), 1-12 \\
\text { https://doi.org/10.52108/2757-5942.1.1.1 } \\
\end{array}$ \\
\hline Çevrimiçi Basım / Online Publication: 28.12.2020 & Geliş Tarihi/Received: 20.12 .2020 \\
\hline
\end{tabular}

\title{
Toplumsal Cinsiyet Rollerinin Televizyon Dizilerine Yansıması Üzerine Sosyolojik Bir Değerlendirme
}

\author{
A Sociological Assessment on the Reflection of Gender Roles on Television \\ Series
}

\author{
Gül AKTAŞ*
}

(D)0000-0001-6424-4256

\begin{abstract}
Öz
Televizyon hem görsel açıdan önemli bir etkiye sahip olmakla birlikte hem de kolay elde edilebilen bir iletişim aracıdır. İzleyici kitlesinin heterojen bir yapıya sahip olması ve karşısındaki kitlenin belirleyici özelliklerini bilmemesine rağmen televizyon yapmış olduğu programlarla bireylerin anlam dünyasını dönüştürebilecek bir güce sahiptir. Bununla birlikte her sosyal gruptan bireye cazip gelecek programları ile izleyicileri etkilemesi televizyonu diğer geleneksel medya türlerinden ayıran en çarpıcı özelliktir. Özellikle toplumda okuma yazma bilmeyen, işitme ya da görme engeli olan bireylerin varlığını düşündüğümüzde her kesime farklı tekniklerle ulaşabilme özelliği televizyonu cazip hale getirmektedir. Televizyonda sunulan haber, eğitim, dizi ve eğlence merkezli programlar kitlelerin beğenilerine sunulurken toplumsal, ekonomik ve kültürel alanda meydana gelen değișimlerden etkilenir. Bu değişimler aynı zamanda bireyin dünya görüşünü, olayları analiz etme ve yorumlama gücünü ve geleceğe ilişkin algı ve beklentilerini de farklı noktalarda etkilemektedir.
\end{abstract}

Son yıllarda özellikle akşam kuşağındaki yerli dizilerde "ideal beden" algısının yoğunlukla kadın aktörler üzerinden sunulduğu bir tablo ile karşılaşmaktayız. Bununla birlikte yerli dizilerde, aile ve sosyal yaşam içinde erkeklerin kadınlar üzerinde kurdukları tahakküm biçimleri, kadınların kendi aralarındaki güç çatışmaları, toplumsal cinsiyete dayalı rol ve sorumluluklar, diyalog ve anlamaya dönük ilişkilerden çok dış görünüşe ve gösterișe yönelik sahneler göze çarpmaktadır. Bu noktadan yaklaștığımızda çalışmanın amacı, son yıllarda televizyonda benzer konu içerikleri ile izleyicilere sunulan yerli dizilerin toplumsal cinsiyetin kültürel temsillerine hangi noktalarda ayna tuttuğu konusunu sosyolojik bağlamda eleștirel bir bakıș açısıyla ele almaktır. $\mathrm{Bu}$ çalışmada, yerli dizilerde toplumsal cinsiyet rollerinin hangi temalarla verildiği konusu araștırılırken, toplumsal cinsiyet eşitsizliğini vurgulayan diyaloglar, kamusal ve özel alana ilişkin kadın ve erkeği konumlandıran mekân görünümleri, estetik ve dış görünüşün ön planda olduğu görsel sunumlar eleștirel bir söylemle analiz edilmeye çalışılmıștır.

Anahtar Kelimeler: İletişim Sosyolojisi, Kadın Temsili, Televizyon Dizileri, Toplumsal Cinsiyet, Ataerkillik

\begin{abstract}
Television is an easily accessible communication tool and has a significant visual impact. Even though the audience has a heterogeneous structure and unknown defining characteristics, television has the power to transform the semantic world of individuals with its programs. Therewithal, the power to attract the audience with its programs that will allure individuals from all social groups is the most noteworthy feature that distinguishes television from other traditional media types. Particularly, the ability to reach every section with different techniques makes television appealing considering the existence of individuals who are illiterate, hearing, or visually impaired. While the news, TV series, education, or entertainment oriented programs are offered to the taste of the audience, they are affected by the changes in economic, social, and cultural fields.
\end{abstract}

\footnotetext{
* Doç. Dr., Pamukkale Üniversitesi Fen Edebiyat Fakültesi Sosyoloji Bölümü. ஐgaktas@pau.edu.tr
} 
These changes also affect the individual's worldview, their ability to analyze and interpret cases, and their expectations and perception about the future at different levels.

In recent years, it has been noticed that the perception of "the ideal body" is mostly presented through actresses in prime-time Turkish TV series. Besides, scenes about physical appearance and vanity are more salient than the scenes about the forms of domination of men over women in the family and social life, power struggles among women, gender-based roles and responsibilities, dialog, and relationships towards understanding. Through this perspective, this study aims to critically analyze from which points Turkish series, which are presented with similar subject contents on television in recent years, mirror the cultural representations of gender in a sociological context. In this study, while the themes of gender roles in Turkish series are investigated, dialogues emphasizing gender inequality, spatial appearances locating women and men in public and private areas, and visual presentations highlighting aesthetics and physical appearance are inquired through critical discourse.

Keywords: Sociology of Communication, Representation of Women in Media, TV series, Gender, Patriarchy

\section{$1 \quad$ Giriș}

Erkekleri ve kadınları birbirinden ayıran biyolojik farklılıklar cinsiyet temelinde incelenir. Buna karşılık toplumsal cinsiyet, kadın ve erkeklerin sosyo-kültürel yaşam içindeki davranış kalıplarını ve bu kalıpların sosyalizasyon sürecinde bireylere nasıl aktarıldığın içeren bir toplumsal şema sunar. Dolayısıyla toplumsal cinsiyete ilişkin kalıp yarglar bir öğrenme süreci içinde gerçekleşir. Toplumsal cinsiyete iliş̧kin şemaya baktığımızda gücü elinde bulunduran genellikle erkektir ve baskın karakter özelliği gösterir. Bu yönüyle erkek, toplumda her zaman varlığını sahip olduğu güç ve otorite ile hissettirir. Kadın ise söz konusu güce tabi olan, kültürel norm, gelenek ve örflerin belirlediği sınırlar içinde yaşamını idame ettiren, daha çok özel alan içinde rol ve sorumluluklar yüklenen bir birey olarak konumlanır. Her ne kadar sanayileşme, küreselleşme ve mesleki uzmanlaşma bağlamında kadınlar kamusal alanda daha görünür hale gelse de yine de kadınların toplumsal yaşamda var olma mücadelesi ve cinsiyete ilişkin kalıp yargıların kırılması yönündeki çabaları farklı boyutlarıyla devam etmektedir.

Toplumsal cinsiyet rollerinin yeniden üretimi geleneksel yapılarda aile içinden başlayarak toplumun diğer mecralarına doğru bir yayılım gösterir. Aile ve sosyal çevrenin dışında medya da bu konuda başat rol oynamaktadır. Kitle iletişim araçlarından televizyon, kadın ve erkek tipolojileri üzerinden cinsiyet ayrımcılığını yeniden üretirken bu süreci aynı zamanda normalleștirmektedir. Özellikle televizyon dizilerinde geleneksel cinsiyet rolleri bağlamında erkeğin evi geçindiren, gücü ve parayı elinde bulunduran, aldatan, duygularını ifade etmekten sakınan; kadının ise, ev içi rollerle sarmalanan, çocukların bakımından sorumlu, erkeğin varlığına koşulsuz ihtiyaç duyan, zaman zaman farklı şiddet türlerine maruz kalan, "erkeği elinde tutmak için" stratejik çözüm yolları arayan, üretmekten çok tüketen bir birey olarak sunulduğu gözlenmektedir. Okuma yazma bilmeyen ve bilgi kaynaklarına doğrudan ulaşma noktasında geri planda kalan ve ataerkil bakış açısının sarmalandığı bir toplumda yetişen kadınları düşündüğümüzde televizyonun toplumsal cinsiyet bağlamında eşitlikçi bir söylemi neden kullanması gerektiği sorusu daha anlamlı olacaktır. Bu çerçeveden baktığımızda toplumun her kesiminden insana ulaşma gücüne sahip olan televizyonun aile içi ilişkiler, kültürel anlam kodları ve toplumsal değerleri nasıl aktardığı sorusu toplumsal cinsiyet ve medya özelinde tartışılması gereken önemli bir sosyolojik konu olarak karşımıza çıkmaktadır.

Özel televizyon ve uydu kanallarının geniş bir yelpazede yayılım göstermesi ile birlikte televizyon, eğlence ve haber programlarının yanı sıra dizi filmlerle bireylerin ilgi dünyalarına zengin bir içerik sunmuştur. Bu nedenle medya son yıllarda iletişim, sosyoloji, psikoloji, radyo-televizyon alanında çalışan bilim insanlarının ilgi odağı haline gelmiştir.

Farklı özelliklere sahip (yaş, cinsiyet, eğitim, toplumsal sınıf vb.) kitlelere popüler kültür ürünlerini bir tüketim nesnesi olarak sunan televizyon dizileri idealize edilmiş yaşam öyküleri ile izleyenlerin 
kimi zaman gerçek yaşamla bağlarını koparmaktadır. Özellikle son dönemlerde dizilerde, evdeki gündelik yaşamlarında gösterişli ve şık giyinen kadınlar, atletik vücuda sahip erkekler, pahalı ve lüks konutlar, dizi boyunca kullanılan mekânların görsel bir şölenle izleyiciye aktarılması, son model gösterişli arabalar, başrol oyuncunun çoğunlukla holding sahibi olduğu yerli diziler popüler hale gelmiştir. Dizilerde öne çlkan unsurlar sadece görsel metinler üzerinden inşa edilmemekte karakterlerin davranış örüntüleri de birbirine benzeyen içeriklerle karşımıza çıkmaktadır. Örneğin dizinin olay örgüsü içinde kadın-kadın veya kadın-erkek ilişkilerinde nefret, intikam, aldatma, güç ve iktidar yarışı, rekabet öne çıkan söylemlerdir.

Tüm bu veriler ıșığında bu çalışma, belirli bir dizi ya da dizilerden yola çıkarak değil, genel bağlamda akșam kuşağında yer alan yerli dizilerde sıkça karşımıza çıkan ve konu-aktör-mekân örgüsünün toplumsal cinsiyet ekseninde nasll işlendiği konusu üzerine odaklanmıştır. Bunu yaparken toplumsal cinsiyet rollerinin hiyerarşik bir cinsiyet algısını nasıl pekiştirdiği, dizideki hikâye örgüsü ve karakterlerin rolleri üzerinden nasıl inşa edildiği eleştirel bir söylemle analiz edilmeye çalışılmıștır. $\mathrm{Bu}$ çerçevede televizyondaki dizilerde kadın ve erkek karakterlerin kullandığı dil ve davranış biçimlerinin nasıl aktarıldığı, dizide kullanılan mekânlar aracılığıyla toplumsal sınıf farklılaşmasının nasıl inşa edildiği, kadın ve erkeklerin özel ve kamusal alan ayrımına göre dizilerde nasıl konumlandırıldıkları ile ilgili sorular irdelenmiştir. Böylelikle bir tüketim aracı olan televizyonun diziler aracılığıyla kadın ve erkeklere verdiği alt mesajlar da bu çalışmada ele alınmış olacaktır.

\section{Toplumsal Cinsiyetin Sosyo-Kültürel İnşası}

Toplumsal cinsiyet terimi ilk kez Ann Oakley tarafından kullanılmıştır. Oakley, 'cinsiyete'le (sex) biyolojik erkek-kadın ayrımını anlatırken; 'toplumsal cinsiyet'le (gender), biyolojik ayrıma paralel olarak toplumsal bakımdan eșitsiz bölünmeye gönderme yapmaktadır. Cinsiyet kelimesinin anlamı zaman içinde sınırlarını genişletmiştir. Son yıllarda daha kapsamlı bir ifadeyle cinsiyet, erkeğin ve kadının toplumsal ve kültürel olarak inşa edilen rollerini tanımlamaktadır. Cinsiyet kavramı, insanların doğuștan getirmiş oldukları fiziksel ve biyolojik bir özellik olarak, bireyleri erkek ve kadın şeklinde iki cinse ayırır. Sadece biyolojik farklılıkların bir göstergesi olmaktan ziyade cinsiyet, yaşamın daha ilk yıllarından itibaren birey için bir toplumsal kategori yaratır. Yaratılan bu kategori, bireyin biyolojik açıdan belli bir cinsten olduğuna ilişkin bilgi dahilinde çeşitli rol, davranış ve tutumlarla şekillenir. Sonuçta birey için toplumsal olarak kabul gören bir roller bütünü belirlenmiş olur. Bu rollere toplumsal cinsiyet denmektedir. Toplumsal cinsiyet ve biyolojik cinsiyet hem birbirine bağımlı hem de birbirinden farklı kavramlardır. Toplumsal açıdan cinsiyet (gender), kadın ve erkeklerin sosyal ve kültürel rol beklentileri olarak tanımlanırken; biyolojik bir kavram olarak cinsiyet, fiziksel farklılıklara gönderme yapar. Dolayısıyla toplumsal cinsiyet, biyolojik cinsiyetin açılamakta yetersiz kaldığı "sosyal sınıf" ve "ataerkillik" gibi kavramların açıklanmasına olanak tanır. Toplumsal cinsiyet kadınlık ve erkeklik arasındaki farklılıkları ortaya koyarken; evrensel bir nitelik taşıyan biyolojik cinsiyetin aksine kültürel açıdan bazı değişkenlikler göstermektedir. Kültürden kültüre farklılık gösteren bu yapı içerisinde kadınlar ve erkekler birbirlerinden belirgin bir biçimde ayrılmakta ve erkekler kadınlara göre öncelikli bir konum elde etmektedir. Toplumsal cinsiyet kadın ve erkeğin, özel ve /veya kamusal alanda nerede duracağı, toplumsal hayata ne oranda katılacağı ve nasıl temsil edileceğini belirler. Burada güç ilişkileri de belirleyici unsur olmaktadır. Öyle ki toplumsal cinsiyete ilişkin inşacı yaklaşımcılar kadın-erkek arasındaki toplumsal farklılıkların güç ilişkilerine göre inşa edildiğini savunurken, güç dengelerinin değiştirilmesi halinde toplumsal cinsiyetin 'doğasının' da değişeceğini ifade etmektedir (Keskin ve Ulusan, 2016: 50).

Ecevit 1970'lere dayandırılan toplumsal cinsiyet çalışmalarında üç önemli aşamadan bahseder: "Bunlardan ilki yukarıda da bahsettiğimiz gibi doğuştan gelen cinsiyet farklarına vurgu yapar. Biyolojik kuram tarafından dile getirilen farklılıkların bilimsel olarak doğrulandığı iddia edilse de kadının sosyal statüsündeki ikincil konumunun gerekçelerini açıklamaktan uzaktır. İkinci aşamada toplumsal cinsiyetin beșerî, dolayısıyla kültürel olduğu gerçeğinden hareket eden bir yaklaşım söz konusudur. Bu yaklaşımın temelinde toplumsal cinsiyet rollerinin sonradan kazanıldığı ve belli bazı toplumsal koşullar ve aktörlerin etkisi ile şekillendiğidir. Bu yaklaşıma göre, söz konusu farklılıklar 
farklı sosyalleşme deneyimlerinden oluşmaktadır. Toplumlarda kadın ve erkeğe özgü cinsiyet rolleri kısmen farklılık gösterse de pek çok toplumda erkek kaynak sağlayıcı, kadın ise aile fertlerini yeniden üretime hazırlayan kişi olarak görülmekte, kadın daha az kaynak ve güce sahip olmaktadır. Cinsiyetler arası hiyerarşinin kaynağı olan ataerkil sistemin bir ürünü olarak karşımıza çıkan bu yapılanma doğum kontrol yöntemlerinin gelişmesi, kadınların eğitim oranlarının yükselmesi ve farklı mesleklere yönelmesi, dolayısıyla doğum oranlarının düşmesine rağmen kadınların neden hala erkeklere göre daha az güce sahip olduğunu açıklayamamaktadır. Üçüncü aşama, toplumsal cinsiyetsosyal sınıf ilişkisine dikkat çekmektedir. Bu aşama toplumsal cinsiyetin bütün sosyal sistemlerde (sınıflı ve ataerkil) merkezi bir rolü olduğuna dikkat çekmektedir. Yani toplumsal cinsiyet, ücretli çalışma, aile, politika, gündelik yaşam, ekonomik kalkınma, hukuk, eğitim ve daha birçok alan analizlerine katılmıştır" (Akt. Altan Arslan ve Güz, 2018:490-491).

Toplumsal cinsiyet rollerinin üretilmesinde ve sürdürülmesinde aile kritik bir öneme sahiptir. Ailenin çocuk yetiştirme biçimleri ve kullanılan dil toplumsal cinsiyete ilişkin kültürel kodların ne şekilde inşa edildiğine dair ipuçları verir. Eğer kız çocuklarına kadınlık kimliğini besleyen, "ev işlerinde becerikli, tutumlu, idare eden, fedakârlık gösteren" bir sosyalizasyon süreci veriliyorsa bu durum ev içi ve annelik normlarının kadın tarafından pekiştirilmesini kolaylaştırır. Buna karşıllık erkeklerin "tahakküm kuran, ev içi sorumluluklardan muaf tutulan, bedensel güç gerektiren işlere yönlendirilen" bir kültürel aktarımla yetiştirilmesi söz konusuysa bu anlayıș ileriki zamanlarda ayrıştırıcı bir dil ile yeniden üretilerek sürdürülen bir davranış kalıbına dönüşür.

Dolayısıyla toplumsal cinsiyet rollerinin üretildiği ilk mecra olan ailede başlayan kültürel aktarım toplumun diğer alanlarına doğru bir yayılım gösterir. Toplumsal cinsiyet rol modellerini aktaran ve yeniden üretimini sağlayan bir diğer mecra olan medya da kritik bir öneme sahiptir. Medya araçlarından biri olan televizyon özellikle geniş kitlelere erişim sağlama kapasitesinden dolayı etki alanı oldukça büyüktür. Bu özelliği ile televizyonun, ataerkil yapının egemen söylemlerini farklı içeriklerle izleyici kitlesine sunması uzun vadede toplumda yaygın bir kanaatin de oluşmasına zemin hazırlamaktadır.

Televizyon, özellikle kadınların bir kısmının çalışmadığı ve evde vakit geçirdiği düşünüldüğünde kritik bir öneme sahiptir. Televizyonun özellikle çalışmayan kadının tek ve yegâne dostu olduğunu belirten Kutlu (2010: 52-54), televizyon dizilerinde toplumsal cinsiyet ekseninde kadının sunumuna ilişkin şu değerlendirmeyi yapar: "Bu kadar çok zaman geçirdiği bir iletişim aracı olan televizyon zamanla kadının duygu ve düşünce dünyasını etkisi altına alan, değer yargılarını değiștiren ve yeni yaşama biçimlerini empoze eden bir araç olmaya başlamıştır. Feminist iletişim çalışmaları, cinsiyet temelli toplumsallaşma ve kalıp yargıların toplumun sürekliliğini sağlamak için yeniden üretilmelerinde televizyonun rolünü sorgulama ya da medyayı kapitalist ve ataerkil sistemi meşrulaştıran ve yayın içerikleriyle bu düzenin yeniden üretilmesini sağlayan ideolojik bir aygit olma çerçevesinde öne çıkarmışlardır."

Medya araçlarına baktığımızda kadınların yer alıș biçimleri hangi program, yazı, araç, görüntü olursa olsun şu ana başlık altında toplanmaktadır: "Şiddete maruz kalan kadın, zavallı ve korunmaya muhtaç kadın, cinsel obje olarak kadın, iyi anne, kötü eş, kötü anne, yuva yıkan ahlaksız kadın, tüketen ve tükettiren kadın" (Söğüt, 2019:217).

\section{Televizyon Dizilerinde Toplumsal Cinsiyet Rollerinin Temsil Ediliş Biçimleri}

Televizyonun yaygınlaşmaya başladığı 50'li ve 60'lı yıllarda kadınlar çok nadiren bağımsız ve olgun bir kişi olarak gösterilmekteydi. Kadınlar ailenin diğer fertlerine özellikle erkek partnerine bağımlı olarak evcil ve özel alanda yer alarak, nadir olarak kamusal alan ve erkek dünyasında görünmekteydi. Raymond Williams televizyonu "teknoloji ve kültürel biçim" olarak tanımlamaktadır. Kültürel biçim olarak televizyon M. Gallagher'e göre toplumda hüküm süren değer yargıları ve ideolojileri 
yansıtmaktadır. 1974 yılında N.S. Tedesco tarafından yapılan araştırmalarda televizyon dramalarında kadınların \%51'inin evli olarak gösterilmesine karşın erkeklerde bu oran \%31 olarak tespit edilmiştir. 1975 yılında J. C. Mc. Neil erkeklerin \%75'inin kârlı işlerde çalıştığını kadınların ise bu oranın yarısından daha az olduğunu ortaya koymuştur. Kadın karakter, yönetici olarak değil de yönetime yakın olan sekreterlik gibi işlerde çalışan daha sempatik bireyler olarak gösterilmektedir. Buna karşılık kadınlar televizyonda, yüksek gücün olduğu dış dünyaya çıkmaktansa evli olmak ve evde tutulmaya uygun olarak gösterilmektedirler (Akt. İmançer, 2000: 99-100).

Türk televizyonunda kadın kimliklerinin nasıl inşa edildiğini araştıran Saktanber, "Cumhuriyet'in kadınlarla ilgili resmî ideolojisi olan ve toplumun modernleşmesine hizmet eden milliyetçi, laik, aile kadını tipini üretmek için, televizyonun kamusal yayıncılık döneminde bir toplumsallaştırma aracı olarak hizmet ettiğini belirtir. Bu dönemde kadınlara yönelik programlarda, saygıdeğer ev hanımları, nazik hanımlar olarak seslenilmektedir. Kadının aile içinde anne ve eş olmasının yanı sıra, bir yurttaş olduğu da belirtilir. 1980'li yıllardan sonra aileyi hedef alan programlar yerine yetişkinlere genel olarak seslenen programlar yer almıştır. Bunlar ev kadınlarının günlük ev işi yapma rutinlerine uygun olarak yayına giren 'Günaydın', 'Günün İçinden', 'Öğle Ü̈zeri' ve 'Öğleden Sonra' gibi programlardır. Bu programlar sosyal güvenlik, toplum içinde yaşamanın kuralları, yaşlılık ve emeklilik gibi konuları içermenin yanı sıra pratik bilgiler, ev ekonomisi ve çocuk bakımı gibi konuları kapsamıştır. Sonuç olarak bu programlar ailenin Türk toplumunun çekirdeği olduğu anlayışıyla hazırlanmış, kadının toplumdaki temel yerinin aile olduğunu vurgulayan programlardır" (Akt. Kutlu, 2010: 73-74).

Türk toplumundaki televizyonun ve televizyondaki programların çeşitlilik göstermeye başladığı dönem özel televizyonların yayına başladığı dönem olarak gösterilebilir. Özel kanalların 1990’lı yılların başında yayın hayatına başlaması ve endüstri toplumunun bir gereği olarak kâr amacı gütmesi yayın politikasını da önemli ölçüde etkilemiştir. Televizyon programlarının yaygınlık kazanmaya başladığı ilk dönemlerde dizilerde gündelik yaşamın içinden kesitler sunan mahalle ve komşuluk ilişkilerinin işlendiği samimi duyguların ve yardımlaşmanın öncelik alındığı içeriklerle hazırlanmış senaryolar geniş izleyici kitlesiyle buluşmuş̧tur. Bununla birlikte televizyondaki yerli dizilerle ev içinde kadının geleneksel rollerini pekiștiren, erkeği ise kamusal alanda görünür kılan bir bakış açısı yeniden üretilerek topluma aktarılmıștır.

Türkiye'de yerli televizyon dizilerinin en önemli çıkışı 2000 sonrasında hem teknik kalite hem de sayısal anlamda yaşanmıştır. Günümüzde ise televizyon dizileri, toplumsal yaşamı biçimlendiren önemli iletişim araçları arasında yer almaktadır. Televizyonda yayınlanan dizilerde toplumsal cinsiyetle ilgili karakter tanımlamalarının, kadın ve erkeğe yüklenen rollerin, ataerkil toplumsal yaşamda kabul gören tanımlamalarla aynı olduğu görülmektedir. Günümüzde televizyon dizilerinin hikâye örgüsü; aile yaşamı, tüketim, toplumsal cinsiyet rolleri, toplumsal statü, güç, başarı, şiddet, zenginlik vb. gibi konulardan oluşmaktadır (Turan, 2019: 127-128).

Denilebilir ki geniş kitlelere ulaşan yerli dizilerin sahip olduğu kurgu toplumsal cinsiyet açısından karakter tasvirleri aracılığıyla ikili karşıtlıklar üzerinden inşa edilmektedir. Buna göre, soğukkanlılık, cesaret, başarı, iktidar, otorite, istikrar gibi özellikler erkek karakterlerle özdeşleştirilirken, sadakat, duygusallık, güzellik, zayıflık, saflık gibi özellikler kadın karakterlerle özdeşleştirilmiştir. Toplumsal hayattaki cinsiyetçi iş bölümünün aynen aktarıldığı dizilerde, kadınlar konumları fark etmeksizin çalışan rolünde olsalar dahi genellikle aile içinde, ev ortamında ve annelik nitelikleri ön plana alınarak gösterilmektedir (Şahnagil, 2019: 223).

\subsection{Toplumsal Cinsiyet Bağlamında Televizyon Dizilerinde Aktarılan Davranış Kalıpları}

Medyanın önemli bir güç olduğu ve küreselleşmenin geri döndürülemez bir konuma geldiği günümüzde dizi izleme alışkanlığı, toplumsal bağlamda basit bir eğlence aracı olmayı aşmış; izleyiciler açısından farklı ve değişik olanı izleme ve tüketme aracına dönüşmüştür. Dahası televizyon dizileri, izleyicinin dünyasına rahatlıkla nüfus ederek insanların algılamalarını ve düşüncelerini 
etkileyip değiştirebilme; belirli konularda kanaat olușturarak tavır almalarını sağlayabilme gücüne sahip olmuştur (Yurderi ve Eminağaoğlu, 2018:1001).

Dolayısıyla medya araçlarından biri olan televizyon, bireylerin tutum ve davranışlarını etkileme ve yönlendirmede önemli bir role sahiptir. Son yıllarda birçok disiplinin araştırma alanına giren medya çalışmalarında televizyon programlarının içeriğinde ataerkil kültürün yansıtılma biçimleri tartışılmaktadır. Özellikle hızla popülerleşen yerli dizilerde toplumsal cinsiyet rollerine ilişkin tutumlar sürekli vurgulanmakta ve pekiştirilmektedir. Böylelikle kadın ve erkekler açısından diziler aracılı̆̆ıyla sunulan karakterler bireyin kendilik algısını da önemli ölçüde etkilemektedir. Dizilerde ön plana çlkan erkek karakterler çoğunlukla, yönetim aşamasında karar merkezinde yer alan, bilgili, başarılı, hırslı, zengin, bağımsız, rekabetçi bir davranış örüntüsü ile verilmektedir. Kadınlar ise yönetim kademesinden uzak, pasif, saf ama kimi zaman entrikacı, fedakâr, anaç davranış örüntüleri ile karşımıza çıkmaktadır. Kadın ve erkeğe ilişkin böyle bir rol tanımlaması izleyici kitleye bir şema sunar. Böylelikle izleyici bu karakterlerden biri ile kendisini ve hayatını özdeşleștirerek toplumsal cinsiyet eşitsizliğini farkında olarak ya da olmayarak onamış olur.

Bu bağlamda yerli dizilerde kadın kimliğinin temsilini "Yaprak Dökümü" adlı dizi üzerinden analiz eden Erdal Aytekin (2018: 454) şu tespitte bulunur: "Medya, kadınlar ve dişillik hakkında sırasıyla stereotipik, ataerkil ve egemen değerleri aktaran temel araçlar olarak algılanır. Bu değerlere bağlı kalınmak suretiyle kadın medyada ya korunması gereken, masum, saf, anne, eş olarak ya da basit, fettan, cinselliği ön plana çıkarılmış kötü kadın olarak yer almaktadır. Her konumda genellikle ikinci plandadırlar, ancak gençlerse mutlaka güzeldirler. Çalışıyorlarsa ev işlerini ikinci plana düşürmeyecek geleneksel kadın mesleklerinde çalışıyorlardır. Öncelik hep anneliğe verilmektedir. Böylece kadının birincil görevi annelik olarak betimlenmektedir. Özellikle reklam filmlerinde kadının; iyi çamaşır yıkanması, iyi yemek yapması, süper anne ve anlayışlı eş olması gerekir. İdeal kadının imgesinin altı bu yolla çizilmiş olur. Bilişsel psikoloji geleneği içinde yapılan deneysel araştırmalar, medyanın -aile ile birlikte- toplumsallaştırma aktörü olarak hareket ettiği varsayımını desteklemektedir. Medya ve aile çocuklara, özellikle kendilerine uygun cinsiyet rollerini öğretmektedir. Böylece toplumda genellikle genel-geçer kurallara göre belirlenmiş olan roller; kadınlara, çocuklara ve erkeklere aktarılır. Neyin, nasıl yapılması gerektiği, kimin görevinin ne olduğu, kimin ne yapması ya da yapmaması gerektiği bu yolla anlatılmış olur."

Varlı Gürer ve Gürer (2020: 647-648)'in ulusal kanallardaki dizilerde kadın karakterlerin nasıl tanımlandığı ile ilgili yapmış oldukları çalışmada, dizilerde kadına biçilen toplumsal cinsiyet rollerinin başında anneliğin geldiğini ifade ederler. Anne olmayan kadın karakterlerin ise "anaç" duygular taşıdığı ve kendisinin sahip olmadığı bir çocuğa ya da kardeşe kol kanat gerdiği gözlenmektedir. Çalışmaya göre, "kadın karakter "cefakâr", "fedakâr" olarak nitelendirilmektedir. Böylelikle kadınlar, kendi hayatları yerine başkalarının hayatını ön planda tutarak onların mutluluğu için çalışan bireyler olarak karşımıza çıkmaktadırlar. Cinsiyete dayalı rollere ait tutumlarda "fedakârlık" genelde kadından beklenen önemli bir davranış olarak aktarılmaktadır. Hayatın kendisine sunduğu tüm zorluklara rağmen hala başkaları için uğraşan kadınlar bu dizilerde betimlenmekte bu da toplumun kadına yüklediği bir davranış kalıbı olarak ele alınmaktadır. Ana kadın karakterlerin sergilediği bir diğer tutum da "ailelerini ayakta ve/veya bir arada tutma" özelliğidir. Kadın, aile olmanın sorumluluğunu taşıyan ve ailenin dağılmasını önleyen olarak betimlenmiştir. Elde edilen sonuçlar genel olarak değerlendirildiğinde toplumun kadın cinsine yönelik yıllardır yapmış olduğu kategorileştirmenin dizilerin sunduğu evrende ana karakterler özelinde devam etmesi önemli bir bulgudur."

Bir başka çalışma olan Turan (2019: 129)'ın, televizyon dizileri ile ilgili yapmış olduğu araştırma şu sonuçları içermektedir: "Kadın karakterlerin \%85'i özel alanda ataerkil toplumun eril baskısını canlı tutan rollerde sunulmaktadır. Aataerkil toplumun kalıplaşmış toplumsal cinsiyet rolü kapsamında kadın karakterlerin \%85'i özel alanda ev içi işler ve çocuk bakımıyla ilgili eş ve anne rollerinde, erkeklerin ise \%87'si kamusal alanda iş içerikli eylemlerde çalışan ve patron rollerinde sunulmaktadır. Televizyon dizilerinde kadınların fiziksel/bedensel görümümü \%55'lik oranla 
popüler kültürün tüketim algısına göre şekillenirken seksi, alımlı ve çekici rollerde sunulmaktadır. Bu araştırma dâhilinde, ataerkil toplumun 'kadın' kavramına yüklediği anlamı $\% 80$ 'lik oranla erkeğe itaat eden ve onların isteklerini sorgulamayan, ailesinin bakımı ile ilgili sorumluluğu üstlenen, toplumsal baskı, taciz, tecavüz ve şiddet mağduru olan rollerle toplumda ötekileştirildiği bulgusu öne çıkmaktadır. Kadınların televizyon dizelerinde şiddet mağduru olma oranı \%55 iken, bu mağduriyetleri çoğunlukla özel alanda eşler/babalar/erkek kardeşler ve diğer aile yakınlarından görmektedirler. Kamusal alanda ise erkek çalışanlar ve patronlar tarafından kadınlar baskıya/tacize ve şiddete maruz kalmaktadırlar."

Medya kanallarından televizyonun kadın imgesine ilişkin davranış kalıpları kadınların genellikle bir erkeğin ekonomik ve sosyal gücüne bağlı ve bu gücü elinde tutabilmek için her türlü meşru olmayan yollara başvurduğu bir betimlemeyle karşımıza çıkmaktadır. TÜSİAD'ın toplumu etkileme potansiyeli yüksek olan televizyonun diziler aracıllğıyla toplumsal cinsiyet rollerini nasıl sunduğu ve toplumsal cinsiyet eșitliğini vurgulayacak söylemlerin nasıl inşa edilmesi gerektiği ile ilgili "Televizyon Dizilerinde Toplumsal Cinsiyet Eșitliği Projesi" önemli bir çalıșmadır. 2018 yllında TÜSİAD'ın öncülüğünde ve İnceoğlu ile Akçalı (2018: 40)'nın yapmış olduğu araştırmayla sonuçlanan bu proje kadınların ve erkeklerin medyada nasıl temsil edildikleri ve toplumsal cinsiyet rolleri açısından nasıl bir rol tanımı içerisine dahil edildiklerini araştırmıştır. Araştırma sonuçlarında dikkati çeken önemli noktalardan bazılarına bakacak olursak: 'ağlama/hüzün' içeren sahnelerin \%73'ünde kadınların yer aldığı, erkeklerin ise bu konuda temsil oranlarının \%27 civarında kaldığı görülmektedir. Öte yandan 'şiddet/tehdit' içeren sahnelerin \%72'sinde erkeklerin baskın oldukları, 'dedikodu/entrika' gibi karakterleri \%60 oranıyla kadınların canlandırdığı, erkeklerin ise \%40 oranda kaldığı ifade edilmiștir. İş hayatıyla ilgili durumları erkekler \%82 oranla temsil ederken kadınların bu anlamda \%18 gibi rakamla kalması ve son olarak da kadınların ev işleriyle alakalı rollerde gösterilmeleri \%92 iken erkeklerin bu konuda \%8'lik bir temsille gösterildiği anlaşılmaktadır." Çıkan sonuçlara bakıldığında toplumda kabul görmüş, yaygın geleneksel kadınlık ve erkeklik algılarının diziler aracılığıyla yeniden üretilerek pekiştirildiği görülmektedir.

Erkek karakterlerin dizilerde ele alınıș biçimi farklı erkeklik tanımlarıyla karşımıza çıkmaktadır. Bu noktada Sancar (2011: 46) erkeklik kavramını açıklarken üst sınıf erkeklik değerlerinin sınıfsal konumlarının kuruluşundaki rolüne dikkat çeker. Ona göre "akılcılık, sorumluluk üstlenme becerisi, yönetme yeteneği sermayeyi yönetecek kişilerin karakteri olmalıdır. Bu tür özelliklerin sınıfsal gerekler olduğu kadar cinsiyet temelli olup ancak erkeklere özgü nitelikler olarak kodlandığı malumdur. Sınıfsal farklar ile farklı erkekliklerin ilişkilenmesi açısından bakıldığında, emekçi sınıf mensubu erkeklerin kas gücü, bedensel güç ile temsil edilen erkeklik tarzı ile orta sınıf profesyonel meslek sahibi erkeklerin teknolojiye dayalı uzmanlık bilgi ve becerisi üzerinden temsil etmeyi tercih ettikleri erkeklikleri arasında bir ortaklıktan çok bir zıtlıktan bahsedilebilir. İlki kollektif, fiziksel güce dayalı, bedensel kapasite odaklı bir erkeklikten, diğeri bireysel, akla dayalı, bedenin üretken gücünün estetik temsiline dayalı bir erkeklikten yanadır."

$\mathrm{Bu}$ noktadan yaklaştığımızda televizyon dizilerinde erkekliğin inşasında ataerkil söylemin izlerini bulmak mümkündür. Dizilerde orta sınıf erkekliğin idealleștirildiği ve normatifleștiği söylenebilir. Belirli bir seviyenin üzerinde düzenli aylık gelire sahip, modern tüketim araçlarını edinebilen, çekirdek aile kurabilmiş ya da kurmaya meyilli kentli bir erkek türü dizilerde hegemonik erkeklik tanımıyla verilmeye çalışılmaktadır. Ancak bunun tam tersi de mevcuttur. Erkeklik söylemi ezilen alt sınıflara kaba bir erkeklik, delikanlılık, harbilik anlatısı da sunar. Her toplumsal kesimin ayrı bir erkeklik tahayyülü ve pratiği vardır. Elinde tesbih sallayan ceketini omuzlarına atmış, topuklarına basarak yürüyen erkek ile takım elbisesiyle bir barda oturan, son model cep telefonu ve araba anahtarı masadayken purosunu tüttüren erkek, erkekliğin farklı görünümlerini ve farklı habitus özelliklerini gösterir (Akt. Özbaş Anbarlı, 2019:93).

Denilebilir ki bireylerin gündelik yaşamın koşuşturmasından uzaklaşabilmek adına izledikleri dizilerle sunulan toplumsal cinsiyete özgü kalıp yargılar bir müddet sonra toplumun önemli bir kesimi tarafından benimsenmekte ve normalleștirilmektedir. Özellikle dizilerdeki yaşam öyküleri 
içinde kendi hayatına ilişkin bir kesit bulan izleyici bir müddet sonra oyuncunun davranış kalıplarını kendisine referans edinir. Bu durum izleyici açısından gerçek ile ideal yaşam arasındaki çizginin kaybolmasına sebep olurken "var olan kimlikle" "yaratılmış kimlik" arasında çatışmalara sebep olmaktadır.

\subsection{Toplumsal Cinsiyet Bağlamında Televizyon Dizilerinde Görselliğin Sunumu}

Güzelliğin günümüzdeki algılanıșı iyi, yüce ve ahlaklı olmak gibi kavramların çok ötesindedir. Güzellik kavramı gibi bedenin içten dışa evrilen öyküsü de doğal olanın reddedilmesine yöneliktir. İdeal vücut ölçülerinin dışında kalan insan vücudu, artık kusurlu olarak değerlendirilmektedir. İnsan güzelliğinin neredeyse evrensel ölçütleri konusunda ortak bir konsensüse varılmıştır. $\mathrm{Bu}$ konsensüsün oluşmasında iktidar ve iktidar organlarının beden politikaları etkili olmakla birlikte, hiç kuşkusuz güzelliğin en önemli nesnesi olan kadının psikolojik ve toplumsal algılanışı da önemlidir. Kadın güzelliğinin nesneleşmesi, yaşadığımız çağın her geçen gün beden merkezli bir konuma gelmesine neden olmaktadır. Bu değişimde medya araçlarının rolü çok açıktır. Medya, kusursuz görünmenin artık doğal olduğunu vurgularken estetik ameliyatlarla yapılan yap-boz bedenlerin meşruluğunu da kutsamaktadır. Bunu yaparken de erkek ve kadın için belli fiziksel kalıplar çizilir; bu kalıplara, özellikle kadınlar girmeye çalışmaktadır (İnceoğlu ve Kar, 2010:193).

Baudrillard (2008:168-169)'a göre, "güzellik; kadın için mutlak ve dinsel bir buyruğa dönüşmüştür. Güzel olmak ne doğa vergisi ne de ahlaki niteliklere bir ektir. Ruhlarına olduğu gibi yüzlerine ve hatlarına özen gösterenlerin temel buyrukçu niteliğidir. Güzel olmak, iş dünyasındaki başarı gibi beden düzeyinde seçilmiş olma göstergesidir. Güzellik, değiş tokuş edilen bir göstergeler malzemesinden öte bir șey değildir. Güzellik gösterge/değer olarak işlev görür."

Görsellik açısından yaklaştığımızda kadın ve erkeklerin medyadaki temsili "yaratılmış beden imgesi" üzerinden inşa edilip farklı içeriklere sahip programlarla izleyici kitlesine sunulmaktadır. Özellikle geleneksel toplumsal yaşam içinde ev içi rollerle temsil edilen kadın saç, makyaj, kıyafet gibi görsel unsurları ön plana çıkarmayan ve diğerleri tarafından fark edilmeyen kadındır. Senaryo içinde kadın kendini fark ettirmek istiyorsa önce dış görünüşünden başlayarak değişime uğramalıdır. Buna karşılık kent yaşamı içinde çalışma ve sosyal hayata katılan kadın modern yaşamın içinde farklı görünümlerle karşımıza çıkmaktadır. Kentli kadın makyaj ve kıyafet gibi unsurlara önem veren, zayıflamak ya da kilosunu korumak için spor ve güzellik merkezlerine giden, beslenmesine dikkat eden kadındır.

Tüketim kültürüne hizmet eden ve beden algısının da bir tüketim nesnesi haline geldiği günümüz medyasında erkek karakterler de kadın karakterler gibi mükemmellik ya da kusursuzluk üzerinden inşa edilmektedir. Atletik ve kaslı bir vücuda sahip olmak, bakımlı olmak, saat, araba, kıyafet gibi görsel unsurlar açısından gösterişli ve lüks tüketim mallarıyla toplumsal statü elde etmek erkek karakterleri izleyici karşısında özel bir yere konumlandırır. Böyle bir erkek imajı onu izleyen seyirci açısından bir model oluşturur.

Bu noktada Baudrillard (2008: 164)'ın “eskiden bedeni sarmalayan ruh idiyse, günümüzde ruhu sarmalayan bedendir" ifadesi medyanın temel söylemi haline gelmiştir. Baudrillard'a göre "insan bedeni bölünmüş çifte bir pratiğe dayanmaktadır: Bu sermaye olarak beden pratiği ve fetiş (tüketim nesnesi) olarak beden pratiği." Bu bakış açısını, günümüz toplumlarında bedenin, bireyin iç dünyasını sarmalayan pek çok duygudan daha önemli olduğu gerçeğini izleyicilere sunan medyadaki programlarda görmek mümkündür.

Görselliğin günümüz dünyasındaki postmodern tüketim algısıyla yeni bir değișim yarattığı yadsınamaz bir gerçekliktir. Tüketim algısının değişen dinamiklerini analiz eden Gedik (2016: 39), bu konuda şöyle bir tespitte bulunur: "Artık tüketim kültürünün yeni özneleri, kendi tüketim tarzlarını bir yaşam projesi haline getirmektedirler. Giysilerini, yaşam pratiklerini, görünüşlerini ve bedenlerini bu yaşam projesi etrafında bir araya getirerek kendi öznelliklerini ve beğenilerini diğerlerine teşhir etmektedirler. Böylelikle nesnelerin tüketimi, yeni imajların ve markaların 
tüketimi aracılı̆̆ıyla yeniden şekillenmektedir. Nesnelerin içerikleri kullanım değerlerinden ziyade gösterge değerleri ile anlam kazanmaya başlamıștır. Tüketim kültürü içinde yaşayan birey, kişisel tercihlerine göre, ürünleri, giysileri, görünüşleri seçerken bir yaşam tarzı oluşturmaktadır. Bu anlamda, tüketim artık işlevsel amaçlarla değil, gösterge değerlerine göre yapılmaktadır denilebilir. $\mathrm{Bu}$ yönden düşünüldüğünde, bireyler tükettikleri ile kültürel semboller yaratarak bir imaj, bir gösterge yaratmaktadırlar. Tüketiciler, kendi kimliklerini oluşturmak için kendi imajlarına yakın bir imaja sahip ürünlere yöneldiklerinde bir ürünün anlamı ve değeri, tüketicilerin kimliklerini oluşturmaya yardım edici rollerini de kapsamaktadır." Bu bağlamda televizyon dizileri ile izleyiciye sunulan imajlar her kesimden bireyin yașamlarına farklı șekillerde sirayet ederek yașam tarzlarını ve yaşama bakış açılarını etkilemektedir. Böylece popüler bir sanatçının giydiği kıyafet, beden dili, konuşma biçimi, davranış örüntüsü diğerlerinin yaşamında yansımasını bularak aynileşen bir kitleye dönüşmektedir.

Denilebilir ki, 21. yüzyılda, yaşamımızın her evresinin değişime uğradığı ve bizi çevreleyen nesnelerin ticarileștiği, hızlı bir tüketime odaklandığı ve "tükettiğin kadar varsın" felsefesi ile hareket edildiği açıtır. Günümüzde sosyal alanda daha aktif hale gelen kadın, daha görünür olması, toplumda erkekle eşit statü kazanması ve artan görünümüyle birlikte dış görünüşüne eskisine göre daha fazla önem vermektedir. Artık, bakımlı, ince ve güzel olmak kadınların görevi olmuştur. Televizyona çıkmanın ön koşulu artık güzel olmaktır. Yüzyıl önce kadınlarda şişmanlık güzellik, doğurganlık ve zenginliğin işareti olarak görülürken dünyaca ünlü Madonna gibi yıldızların ve benzeri medya imajlarının rol-model olarak alınması sonucunda zayıflık güzellik normu olarak tüm dünyada yayılmıştır. Zayıf, sıkı olmak, genç kalmak kadınlar için birer takıntı haline gelmiştir. Önceleri ekonomik durumu nedeniyle beslenme sonucu zayıf kalan kadın, şimdilerde durumu uygun olmasına karşın kendi isteği üzerine hatta fazladan çaba göstererek zayıflamak için aç gezmektedir. Şişmanlık kendini kontrol edememe, disiplinsiz ve sağlıksız olarak algılanmaktadır. Günümüzde zayıflığın bir ideal olarak görülmesinin nedeni Foucault gibi düşünürler tarafından ataerkil toplumda kadın bedenini kontrol altına alma, sınırlamanın bir sonucu olarak algılanmaktadır (Akt. Çonkarlı, 2018: 20-25).

Beden imgesinin üretildiği ve medya aracılığıyla bireylere görsel imgelerle aktarıldığı günümüz toplumunda kadın ve erkek temsilleri izleyici kitlesi tarafından beğeni toplamaktadır. Bu durum bir süre sonra erkek ve kadın açısından görsel olarak kusursuz görünme çabasının tüketim kültürüne hizmet ettiği bir sürecinde kapısını aralamaktadır.

\subsection{Toplumsal Cinsiyet Bağlamında Mekân Örgüsünün Televizyon Dizilerinde İşlenişi}

Görsel bir gösterge niteliğindeki mekân, dizilerdeki diğer unsurlarla birlikte, toplumsal değer değişiminin ortaya konmasında önemlidir. Taşçıŏlu, mekânın zamanla çatı olmaktan öteye giderek, insanları ayıran, birleştiren, insan etkinliklerini organize eden, insanın düşünce ve duygularını pekiştiren ya da değiştirebilen ve onu denetim altına alabilen bir yapı haline geldiğini; bu yapının şekillenmesinde politik ve ticari kaygılar kadar bireysel tercihler, kültürel ve fiziksel farklılıkların rol oynadığını anlatmaktadır. Mekân, kişisel ve toplumsal yaşamdaki değişimleri yansıtabilir. Zira yaşama anlam kazandıran, içinde ve birlikte yaşanan mekânlardır. Mekân aynı zamanda tarihsel süreçte değișen, dönüşen bir niteliğe sahiptir ve bu anlamda sosyolojik bir bilgi kaynağı oluşturmaktadır. Mekânsal değișimler ise görsel kodlar olarak ele alındığında toplumsal değişimlerin birer göstergesi olarak değerlendirilebilir. Bu bağlamda medya aracıllğıyla yaygınlaşan kültürel küreselleşme, mekânların yeniden dönüşmesinde etkili olmuş; kültürel bir değişim yaşanmasına yol açmıştır (Akt. Yurderi ve Eminağaoğlu, 2018:1000-1001).

Televizyonun yayın hayatına başladığı ilk yıllarda teknolojik donanım açısından düşünüldüğünde gündelik yaşama özgü daha sade ve gösterişten uzak mekânlar üzerinden programlar yapılmıştır. Mahalledeki komşuluk ve akrabalık ilişkilerinin ön planda olduğu, yerel kültüre özgü değerlerin sıkça işlendiği, dönemin ekonomik ve toplumsal değişim izlerinin yansıtıldığı 1970'li yıllardaki diziler 1980’li yıllara geldiğinde önemli bir dönüşüme uğramıştır. 
Küresel kültürel etkileşim, 1980 sonrasında giderek artmış; böylece kültürel değişim ve dolayısıyla değer değişimi her alanda olduğu gibi medya kanallarını da etkilemiştir. 1990'lı yıllarla birlikte hızlanan küreselleşme, kültürel değerleri tehdit edebilecek bir niteliğe bürünmüștür. Ulusal kültürlerin bu yolla zayıflaması ve zaman içinde melezleșmesiyle, post modern kültür yaygınlaşmış; böylece yeni yaşam biçimleri ve yeni değerler ortaya çıkmıştır (Yurderi ve Eminağaoğlu, 2018: 1001).

2000'li yıllarla birlikte Türk televizyon yayıncılığında yeni bir dönüşüm meydana gelmiştir. Bu yıllarda Anadolu'yu mekân olarak tercih eden geleneksel toplumsal ilişkileri temel alan yapımlar giderek yoğunluk kazanmıştır. Buna bağlı olarak dizilerdeki olay örgüleri taşraya dönmüş, ağa ve bey gibi feodal yapının unsurları izleyiciye çeşitli güzellemeler içerisinde verilmeye başlanmıştır. Söz konusu dönüşümün ikinci basamağını ise 2000 'li yılların ortalarında dizi senaryolarının İstanbul'un burjuva kesimine odaklanmaya başladığı süreç oluşturmaktadır. Sembollerini lüks evlerin, villaların, arabaların veya lüks kıyafetlerle yalıların oluşturduğu bu dönemde dizi kahramanları genel toplumsal tabakadan ayrı bir profil çizmiştir (Şahangil, 2019: 224).

Televizyon dizilerinde tüketime yönelik mekânsal alanlar tüm ihtişamıyla göz kamaştırırken bireylerin hayal dünyaları da "idealize edilmiş" bu yaşam alanları ile yeni bir kimliğe bürünmüştür. Bununla birlikte televizyon dizilerinde kadın ve erkekler geleneksel rol ve sorumlulukları bağlamında gündelik yașam pratikleri açısından ayrı mekânlar üzerinden tanımlanmıştır. Mekânsal ayrışma toplumsal cinsiyet söylemlerine ilişkin önemli alt mesajları da içinde barındırmaktadır. Dizilerde kadın aktörlerin çoğunlukla özel alanla özdeşleşirken erkek aktörlerin kamusal alanla özdeşleştirilmesi tesadüf değildir. Bu bağlamda TÜSİAD'ın öncülüğünde yapılan çalışma önemli veriler ortaya koymaktadır. Çalışmada, "patron/işveren/yönetici olarak konumlandırılan erkeklerin toplam erkek karakterlere oranı $\% 40$ olarak tespit edilirken kadınların oranı \%11'de kalmaktadır. Bunun da ötesinde, bu rollerdeki erkeklerin sahneler bazından görünürlük oranı \%89'a çıkarken kadın karakterlerin görünürlükleri sadece \%11 olarak yer almaktadır." Dolayısıyla söz konusu projenin verilerine baktığımızda dizilerde mekânın, kamusal ve özel alan ayrımı üzerinden inşa edilirken toplumsal cinsiyet eşitsizliğinin yeniden üretildiğini de görmek mümkündür (İnceoğlu ve Akçalı, 2018: 43).

\section{Sonuç ve Öneriler}

Medyada sunulan kadın kimliği farklı program ve içeriklerle giderek erkek egemen bir söylemle karşımıza çıkmaktadır. Özellikle televizyondaki dizilerde kadın, "kırılgan", "pasif", "kolay elde edilebilir", "yönetilebilir" bir anlayışla ele alınmakta ve yeniden üretilerek normalleştirilmektedir. Televizyon dizilerinde son yıllarda hikâye örgüsü içerisinde en çok karşımıza çıkan "evlenme", "yuva kurma", "çocuk doğurma" gibi taleplerin çoğunlukla kadınlar üzerinden işlenmesi ve kadınların öncelikli görevlerinin ev içi sorumluluklar olduğunun hatırlatılması sıklıkla dile getirilmektedir. "Evlenme" ve "anne olma" dizilerde kadın izleyici kitlesine farklı olay örgüsü ile yükselen değer olarak sunulmakta ve izleyicilerin o rol ile özdeşleşmesi sağlanmaktadır. Televizyon dizilerinde evlenmek için her tür stratejik yöntemin kadınlar tarafından kullanıldığı, evliliğin meslek ve eğitim hayatının önüne geçtiği, âşık olduğu kişi için eğitim hayatını yarıda bıraktığı, eşi ya da sevgilisi istemediği için çalışmadığı, ekonomik açıdan bir erkeğe bağımlı olan kadın imgesi ağırlıklı olarak işlenen konulardır. Geleneksel medya araçlarından televizyonun geniş kitlelere ulaşması ve bireyin anlam dünyasını şekillendirmesi gerçeğinden yola çıktığımızda toplumsal cinsiyet kalıp yargılarının dizilerdeki sunumu kritik bir önem arz etmektedir.

Farklı yıllarda tekrar eden bir çalışma örneği medyadaki kadın temsilinin değişmediğini göstermektedir. 1995, 2000, 2005 ve 2010 yıllarında yürütülen bir araştırma projesi örneği olan Küresel Medya İzleme Projesi (Global Media Monitoring Project) 15 yıllık dönem boyunca medya profesyonelleri veya haber aktörleri olarak kadınların pozisyonlarında çok az bir ilerleme sağlandığına dair bilgi vermektedir. Buna ilaveten, bu çalışmanın önemli bulgularından biri de kadınların nadiren haber özneleri olarak tasvir edilmeleridir. Kadınların medyadaki görünümünü sağlıklı bir hale dönüştürmek için bazı çabalar verilmiş olmasına rağmen, mevcut durumda kadınların medyadaki temsilinde geçmişten günümüze çok fazla yol alındığı söylenemez. Belirli 
stereotipler çerçevesinde kadınların medyadaki temsili bu açıdan problemli bir şekilde devam etmekte ve kadınların çalışma hayatı veya aile hayatı içerisindeki rol ve sorumlulukları, medyanın görünmeyen normları haline gelmekte ve medyatik ürünler şeklinde yeniden üretilmektedir. Medyanın geçmişi, bugünü ve geleceği arasındaki ilişki biçimi, geleneksel toplumsal cinsiyet normları ve davranış kalıplarını yansıtan bir görünüm yaratmaktadır. Feminist politikada tartışılan özel ve kamusal alan ayrımına ilişkin kadınlardan beklenilen davranış biçimlerine, cinsiyetçi dil ve söylemiyle medya da eklemlenmektedir (Orçin, 2020: 98-99).

İçerik üreten medya profesyonellerinin toplumsal cinsiyet söylemlerini izleyici kitleye ulaştırırken kritik bir görev üstlendiği gerçeğini göz ardı etmemesi gerekir. Bu sebeple medya, daha eşitlikçi, kadın ve erkek açısından paylaşılabilir rol ve sorumlulukların yoğun olarak anlatıldı ı̆ı, şiddet ve onun türevlerinden uzaklaştırılmış bakış açısının sunulduğu bir misyon yüklenmesi gerekmektedir. Bir diğer ifadeyle senaristlerin dizi hikayelerini oluştururken eşitlikçi bir söylemi vurgulayan temaları ön plana çıkarmaları kritik bir önem arz etmektedir. Kadının erkek kadar kamusal alanda görünürlüğünü, eğitim ve meslek hayatında var olabilirliğini önceleyen projelere imza atan bir medya anlayışı toplumsal cinsiyet kalıp yargıların da çözülmesini sağlayacaktır. Bu durum toplumsal farkındalığın artmasına hizmet ederken kuşaklararasında aktarılan eşitlikçi bir dilin de yaygınlaşmasına zemin hazırlayacaktır. Son yıllarda kadına şiddet olgusunun arttığı, duygusal ilişkilerin hızlı ve acımasız bir biçimde tüketildiği, boşanma sürecinin ardından kadın ve çocuklar açısından yaşanan travmatik olaylar dikkate alındığında dizilerde kullanılan eşitlikçi bir dil ve bakış açısının bireylerin yaşamını da iyileştirebileceği kanaatindeyiz. Ancak bu şekilde medya ve onun alt alanları daha sağlıklı birey ve toplum yaratma görevini yerine getirmiş olacaktır.

Tüm bu belirtilenler ışığında baktığımızda denilebilir ki, insanların toplumsal, ekonomik ve kültürel yaşamlarındaki yoğun ve stresli süreci atlatmak için yöneldikleri televizyon programlarının toplumsal gerçekliğe ışık tutacak, eğiterek düşündürecek ve en önemlisi de son yıllarda artış gösteren kadın-erkek ilişkilerindeki nefret söylemini ortadan kaldıracak bir içeriğe kavuşması gerekmektedir.

\section{Kaynakça}

Altan Arslan, Ş., Güz, H. (2018). Eril ve Dișil Cinsiyet Rollerinin Medyada Sunumunun Arka Planı: İletişim Fakültesi Öğrencilerinin Cinsiyet Algıları Üzerine Bir Araştırma, İletişim Kuram ve Araştırma Dergisi, 47, s.487-506.

Baudrillard, J. (2008). Tüketim Toplumu Söylenceleri/Yapıları, Hazal Deliceçaylı, Ferda Keskin (Çev.). İstanbul: Ayrıntı Yayınları.

Çonkarlı, M.S. (2018). Türk Televizyon Dizilerinde Yansıtılan Kadın İmgesi: Aşk-ı Memnu Örneği. Yayınlanmamış Yüksek Lisans Tezi, Maltepe Üniversitesi, İstanbul.

Erdal Aytekin, P. (2018). Yerli Dizlilerde Kadın Kimliğinin Temsili Üzerine Bir Örnek; "Yaprak Dökümü" Dizisi. Erciyes İletişim Dergisi, 5 (4), s. 447-463.

Gedik, E. (2016). Bir Tüketim Kültürü Ürünü Olarak Anti-Kahraman Erkek İmajları. ViraVerita EDergi, 4, s. 37-58.

İmançer, D. (2000). Televizyonda Toplumsal Cinsiyet Sembollerinin Türk Aile Dizilerinde Sunumu. Yayınlanmamış Doktora Tezi, Ege Üniversitesi, İzmir.

İnceoğlu, İ., Akçalı, E. (2018). Televizyon Dizilerinde Toplumsal Cinsiyet Eşitliği Araştırması, Ebru Dicle, Ezgi Çelik (Ed.), TÜSİAD.

İnceoğlu, Y., Kar, A. (2010). Dişillik, Güzellik ve Şiddet Sarmalında Kadın ve Bedeni. İstanbul: Ayrıntı Yayınları. 
Keskin, F. ve Ulusan, A. (2016). Kadının Toplumsal İnşasına Yönelik Kuramsal Yaklaşımlara Dair Bir Değerlendirme. Akdeniz Üniversitesi İletişim Dergisi, 26, s. 47-68.

Kutlu, A. (2010). Televizyon Dizilerinde Toplumsal Cinsiyet Açısından Kadının Sunumu: Kanal D’de Yayınlanan Yaprak Dökümü Dizisinde Kadın Karakterler. Yayınlanmamış Yüksek Lisans Tezi, İstanbul Üniversitesi, İstanbul.

Orçin, G. (2020). Eril Tahakkümün Medyatik Temsili: Popüler Bir Kadın Avukat Portresi. Kadın Çalışmalarına Sosyolojik, Kültürel ve Edebi Bir Bakış kitabı içinde. Gizem Orçin, Yasemin Ağaoğlu (Ed.), Ankara: Iksad Publishing House.

Özbaş Anbarlı, Z. (2019). Dijital Televizyon Dizilerinde Hegemonik Erkeklik. Erciyes İletişim Dergisi, Uluslararası Dijital Çağda İletişim Sempozyumu Özel Sayısı, s. 81-104

Sancar, S. (2011). Erkeklik: Imkânsız Iktidar. İstanbul: Metis Yayınları.

Söğüt, F. (2019). Yeni Medya ve Temsil: İnternet Gazeteciliğinde Toplumsal Cinsiyet Kimliklerinin Sunumu. Akdeniz İletişim Dergisi, 31, s. 212-231.

Şahangil, S. (2019). Kültür ve Medya İlişkisi Kapsamında Kadın İmgesi: Geleneksel Cinsiyet Rejiminin Dizilerle Yeniden Üretimi. II. International Conference on Empirical Economics and Social Sciences, June 20-22 Haziran, Bandırma

Turan, H. (2019). Televizyon Dizlilerinde Kadın Temsili. Yayınlanmamış Yüksek Lisans Tezi, Süleyman Demirel Üniversitesi, Isparta.

Varlı Gürer, S. Z., Gürer, M. (2020). Toplumsal Cinsiyet Rolleri Bağlamında Türkiye'deki Televizyon Dizilerinde Sunulan Kadın Stereotipi. Alanya Akademik Bakış Dergisi, 4 (3), s. 631-650.

Yurderi, M. M., Eminağaoğlu, Z. (2018). TV Dizilerindeki Değer Temsillerinin Mekânsal Kullanımlar Aracılığıyla Karşılaștırılması. Uluslararası Sosyal Araștırmalar Dergisi, 11 (57), s. 1000-1008.

\section{Kaynak Gösterimi / Cite This Article}

APA:

Aktaş, G. (2020). Toplumsal Cinsiyet Rollerinin Televizyon Dizilerine Yansıması Üzerine Sosyolojik Bir Değerlendirme. Sosyolojik Bağlam Dergisi, 1(1), 1-12.

Aktaş, G. (2020). A Sociological Assessment on the Reflection of Gender Roles on Television Series. Journal of Sociological Context, 1(1), 1-12.

MLA:

Aktaş, Gül. "Toplumsal Cinsiyet Rollerinin Televizyon Dizilerine Yansıması Üzerine Sosyolojik Bir Değerlendirme." Sosyolojik Bağlam Dergisi, c. 1, s. 1, 2020, ss. 1-12.

Aktaş, Gül. "A Sociological Assessment on the Reflection of Gender Roles on Television Series." Journal of Sociological Context, v. 1, i. 1, 2020, pp. 1-12.

\section{Chicago:}

Aktaş, Gül. "Toplumsal Cinsiyet Rollerinin Televizyon Dizilerine Yansıması Üzerine Sosyolojik Bir Değerlendirme." Sosyolojik Bağlam Dergisi 1, s. 1 (2020): 1-12.

Aktaş, Gül. "A Sociological Assessment on the Reflection of Gender Roles on Television Series." Journal of Sociological Context 1, i. 1 (2020): 1-12. 